\title{
Submesoscale, tidally-induced biogeochemical patterns in the Strait of Gibraltar
}

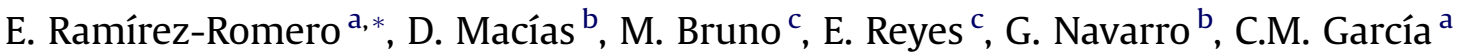 \\ ${ }^{a}$ Departamento de Biología, Área de Ecología, Facultad de Ciencias del Mar y Ambientales, Universidad de Cádiz, Avda. República Saharaui sn., 11510 Puerto Real, Cádiz, Spain

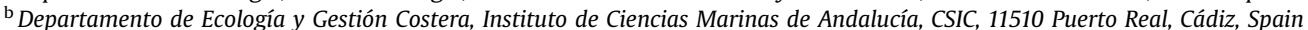 \\ ${ }^{\mathrm{c}}$ Departamento de Física Aplicada, Facultad de Ciencias del Mar y Ambientales, Universidad de Cádiz, 11510 Puerto Real, Cádiz, Spain
}

\section{A R T I C L E I N F O}

\section{Article history:}

Received 7 July 2011

Accepted 7 February 2012

Available online 22 February 2012

\section{Keywords:}

Alboran Sea

Strait of Gibraltar

tidal mixing

internal waves

water masses

biogeochemical patterns

\begin{abstract}
A B S T R A C T
Tidal forcing and its fortnightly variation are known to be one of the main regulating agents of physical and biogeochemical signatures in the Strait of Gibraltar and surrounding areas. Samples obtained during spring and neap tides in the region were analyzed to determine the influence of this tidal variation on the submesoscale distribution of water masses and biological elements. During spring tides, strong and intermittent mixing processes between Mediterranean and Atlantic waters occur in the vicinity of the Camarinal Sill together with an eastward advection of those mixed waters into the Alboran Sea. Furthermore, the intense suction of surface coastal waters into the main channel of the strait was detected as chlorophyll patches in the Alboran Sea during spring tides. In contrast, the most characteristic phenomenon during neap tides was the arrival of pulses of relatively nutrient-rich North Atlantic Central Waters to the surface regions of the Alboran Sea. In addition, traces of the suction of coastal waters were observed for the first time during neap tides. Therefore, our results show that submesoscale processes are crucial in the dynamics of the Strait of Gibraltar, and they must be considered for the correct description of the biogeochemical features of Alboran Sea, especially during an inactive period of the coastal upwelling.
\end{abstract}

(c) 2012 Elsevier Ltd. All rights reserved.

\section{Introduction}

The Strait of Gibraltar is the only connection between the Mediterranean Sea and the Atlantic Ocean, with a minimum width and sill depth of approximately $14 \mathrm{~km}$ and $300 \mathrm{~m}$, respectively. The water circulation in the strait is described as "inverse-estuarine", characterized by a surface inflow of Atlantic waters and a deep outflow of denser Mediterranean waters that is ultimately driven by an excess of evaporation over precipitation in the latter basin (Lacombe and Richez, 1982). The description of the exchange as a simple one-dimensional, two-layer system flowing in opposite directions is a good first approximation (Armi and Farmer, 1985), but it is deficient in describing the 2D distribution of some variables and their changes across and along the main channel of the strait.

The hydrodynamics of the strait are so intense that they can be considered the most important forcing on the distribution and behavior of biogeochemical variables (e.g., Macías et al., 2007). The hydrological processes in the strait, as in other coastal regions, cover a wide range of temporal scales including interannual, seasonal, sub-inertial and tidal (Lacombe and Richez, 1982). Much

\footnotetext{
* Corresponding author.

E-mail address: Eduardo.ramirez@uca.es (E. Ramírez-Romero).
}

attention has been paid to tidal forcing and its effects on alongstrait circulation, including the hydraulic control of flow (Armi and Farmer, 1985; Izquierdo et al., 2001), tidal transport through the strait (Bryden et al., 1994; García Lafuente et al., 2000) and the vertical structure of the tidal currents (Bruno et al., 1999; Tsimplis and Bryden, 2000; Sánchez-Román et al., 2008). Essential processes in the physical-biological coupling in this area involve the large amplitude internal waves generated in the Camarinal Sill by the interaction between tidal flows and bottom topography (Armi and Farmer, 1985; Bruno et al., 2002; Vázquez et al., 2008).

Subinertial flows, with periods ranging from days to months, have been found to be principally forced by the atmospheric pressure fluctuations over the western Mediterranean Sea (Crepon, 1965; Candela et al., 1989; García Lafuente et al., 2002; Vázquez et al., 2008). Both Candela et al. (1989) and García Lafuente et al. (2002) found that sub-inertial barotropic flows were consistently counter-phase $\left(180^{\circ}\right)$ to the atmospheric pressure fluctuations for oscillating periods between 3 and 80 days. Thus, within this period range, an increase (or decrease) in the atmospheric pressure over the Mediterranean is followed by a subsequent decrease (or increase) in the intensity of the Atlantic inflow. This modulation of the inflow velocity has also been found to have an effect on the position of the Atlantic Jet and Western Alboran Gyre (Macías et al., 2008a). The opposite effect of this meteorological forcing can be 
observed in the velocity of the Mediterranean outflow; thus, these atmospheric pressure oscillations can either reinforce or inhibit the generation of internal waves (Vázquez et al., 2008).

There have been a number of studies on the biogeochemical features within the strait and the physical-biological coupling in the region. However, most research concerning the physical-biological coupling in the area has been devoted to studying the 1D along-strait dynamics. There are at least three main water masses involved in the circulation through the strait (Gascard and Richez, 1985): Surface Atlantic Water (SAW), NACW and Mediterranean Outflowing Water (MOW). In a west-east section, the position of the Atlantic-Mediterranean Interface (AMI) and the distribution of the nutrient-enriched NACW are dependent on the fortnightly tidal amplitude variation (Gascard and Richez, 1985; Gómez et al., 2001; Macías et al., 2006). Tidal forcing controls the pulsating mixing processes occurring in the Camarinal Sill, which, in turn, conditions the presence of patches with high chlorophyll concentrations within the Atlantic Jet (AJ) (Macías et al., 2006). Also, the pulsating presence of the different types of water masses throughout the tidal cycle conditions the presence of different chlorophyll maxima associated to specific water interfaces (Macías et al., 2008b; Bartual et al., 2011).

Recent studies, however, have suggested the importance of submesoscale processes and the 2D interaction between the coastal zones and the main channel in creating the biological signatures found within the strait. Using a coupled physical-biological model and field data, Macías et al. (2007) found that the high chlorophyll patches at the eastern section of the strait could not be explained by in-situ growth of phytoplankton triggered by the fertilization of the upper layer, as had been previously suggested (e.g., Gómez et al., 2000; Echevarría et al., 2002). The authors suggested that the existence of a surface divergence just east of the Camarinal Sill, as simulated by the model of Izquierdo et al. (2001), could induce not only the ascent of the interface, but also a lateral advection of coastal waters into the center of the channel during the maximum outflowing current shortly before high water time.

These coastal chlorophyll-enriched waters would then be advected toward the Mediterranean Sea, which explains the previously observed pulsating patterns of chlorophyll in the AJ (Macías et al., 2006). This hypothesis was recently confirmed by Vázquez et al. (2009), who used in-situ data and satellite images showing how the generation of internal waves induced transport of chlorophyll-enriched coastal waters to the channel and their advection toward the Alboran Sea. Bartual et al. (2011) found evidence of a change in the plankton primary production pattern concomitant with the presence of an internal bore in the main channel of the strait, which was consistent with the arrival of active coastal plankton communities.

Nevertheless, the 2D nature of the current field and associated biological signatures has not been rigorously assessed. Previous works have described the 2D characteristics of the strait (Gómez et al., 2000; Echevarría et al., 2002), although the variability due to the tidal cycle was not taken into account properly because of a sampling resolution that was inadequate in resolving this shortscale variability (i.e., hourly). These previous studies elucidated two mechanisms that can support the high phytoplankton biomass on the eastern side of the strait: (1) a shallower position of the AMI toward the north-east and (2) an injection of nutrients into the upper layer by mixing processes due to hydraulic jumps or arrested topographic waves above the Camarinal Sill. Nevertheless, these works did not analyze the submesoscale phenomena described above, which are known to be critical in the dynamics of this ecosystem.

The present work is the first comprehensive description of the submesoscale 2D structure of water mass distributions and biogeochemical signatures within the Strait of Gibraltar for the analysis of tidal-scale patterns and meteorological-induced variability. We will focus on the tidal-scale, highlighting the differences between spring and neap tide periods and proposing mechanisms for the observed distribution patterns that take into account the local conditions (i.e., the tidal amplitude and phase) and climatic conditions over the Mediterranean basin.

\section{Materials and methods}

\subsection{Data analysis}

Data were obtained on a cruise during September and October of 2008 on the research vessel B/O "Sarmiento de Gamboa". The study area covered the Strait of Gibraltar and the western Alboran Sea (Fig. 1), and it was surveyed twice to account for the fortnightly tidal variability; thus, the data was acquired under different tidal conditions (spring and neap tides). All 53 stations were sampled twice (once during spring and once during neap tides). The different grids obtained were designated "D1" for the spring tide phase and "D2" for the neap tide phase (Fig. 2A, B).

A combined CTD probe (Seabird SBE-911) was used to register the physical structure of the water column and the distribution of water masses. Median of data from the upper $75 \mathrm{~m}$ of the water column was used for all the variables. Following the time-averaged transport and interfaces structure simulated in a 3-layer hydrodynamic model by Sannino et al. (2007), this section of the water column (including the Atlantic and/or the interfacial layer) finally enters into the Alboran Sea.

The interface between the Atlantic and Mediterranean Waters (AMI) was assumed to correspond to the 37.5 isohaline westward of the Tarifa Narrow (Fig. 1) and the 37 isohaline eastward of this point (Gascard and Richez, 1985; García Lafuente et al., 2002). The presence of NACW was determined by examining each CTD profile and was denoted by the presence of salinities $<36.2$ (Gascard and Richez, 1985). The presence of this water mass is denoted by a square on the map, and triangles indicate its absence (see Results, 3.1).

Water sample data from 5, 25, 50, and $75 \mathrm{~m}$ were compared to the CTD records. Total chlorophyll was estimated from 0.5-L seawater samples filtered through Whatman GF/F filters using the fluorimetric method described by Yentsch and Menzel (1963) and modified by Holm-Hassen et al. (1965). The fluorescence data from the CTD's vertical profiles was converted to units of chlorophyll by a linear equation using Least square fitting method $(r 2=0.68$, $p$-value $<0.01$ ) using 256 bottle samples in which the chlorophyll concentration was measured.

The percentage of larger cells (i.e., microphytoplankton) was estimated by comparing the amount of chlorophyll extracted from

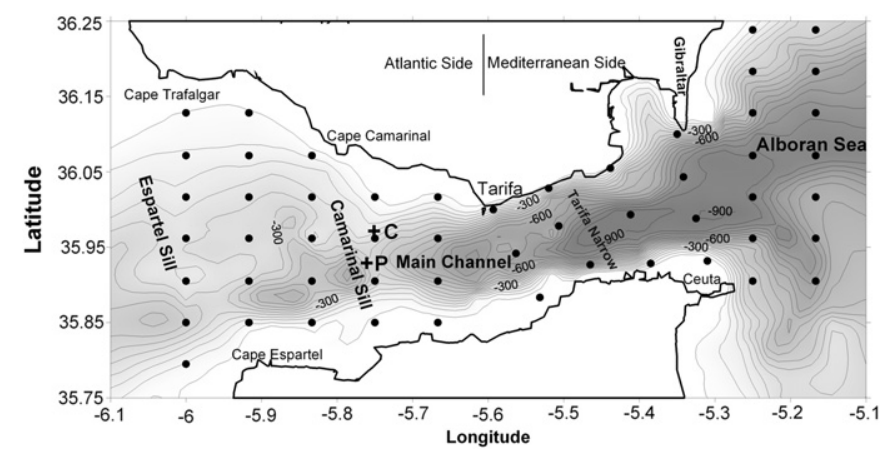

Fig. 1. Map showing the location and main geographic points of the study area. "C" marks the location of the current meter over the Camarinal Sill at a depth of $100 \mathrm{~m}$ "P" marks the location of the currents predicted. 


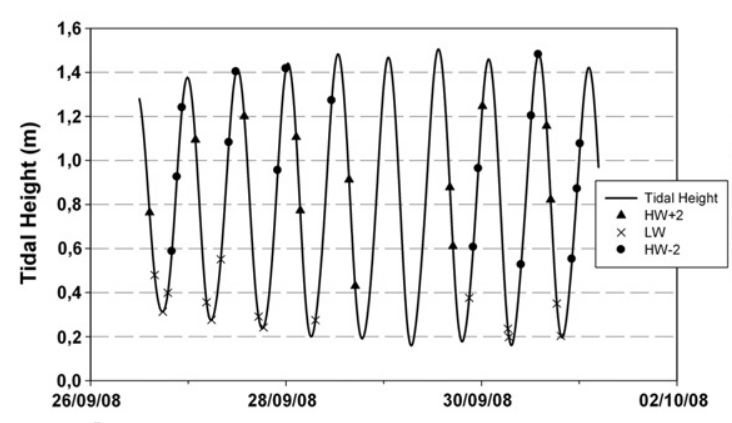

A

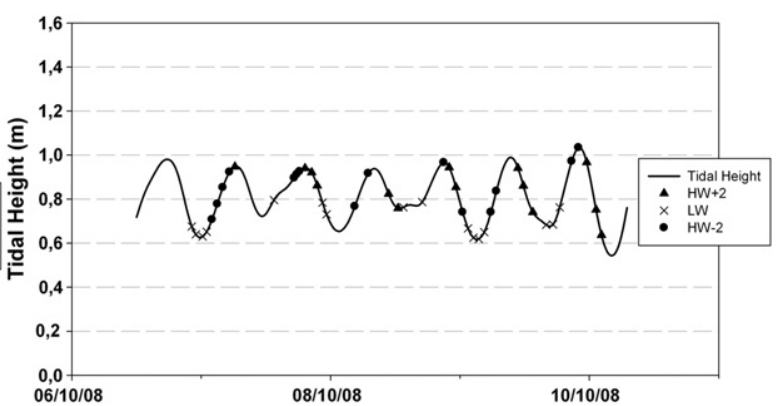

B

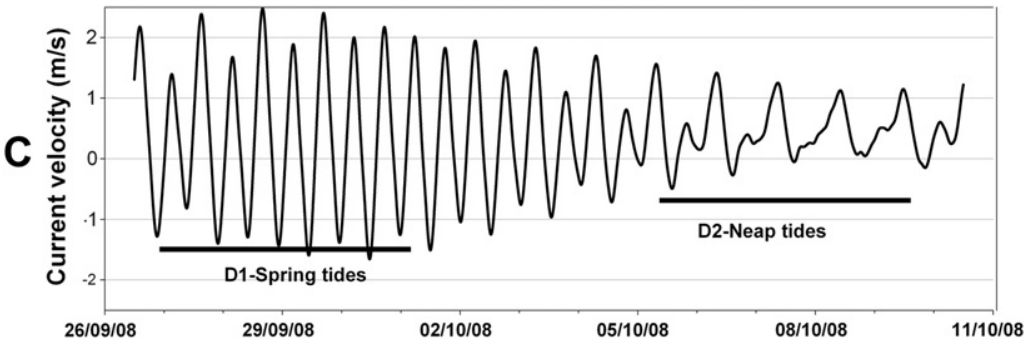

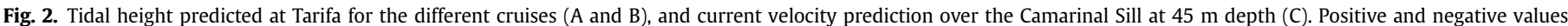
indicate currents toward the Mediterranean and Atlantic, respectively.

the fraction of particles retained on a $20-\mu \mathrm{m}$ mesh to the total chlorophyll concentration. This is referred to as the percentage of chlorophyll contained in cells larger than $20 \mu \mathrm{m}$. Five liters of seawater were filtered through a nylon mesh with a $20-\mu \mathrm{m}$ nominal pore size. The fraction retained on the mesh was then collected by washing it with clean, filtered (Whatman $\mathrm{GF} / \mathrm{F}, \approx 0.7 \mu \mathrm{m}$ ) seawater. This fraction was filtered again through a Whatman GF/F filter, and its chlorophyll content was determined following the same fluorimetric protocol described above for total chlorophyll.

The percentage of active chlorophyll was estimated using a Pulse Amplitude Modulated (PAM) fluorometer specifically designed to study phytoplankton cells (PhytoPAM ${ }^{\odot}$, see Kolbowski and Schreiber (1995) for a detailed description). The PhytoPAM provides an estimate of the proportion of total chlorophyll within active PS II (i.e., the chlorophyll available for photosynthesis (Kolberg and Falkowski, 1993)) or "active chlorophyll." The measurements were done on board with dark-adapted seawater samples from each station and depth as in Macías et al. (2008b, 2009).

In order to examine the associations between the different biological variables, and trying to avoid showing redundant information and plots; a principal component analysis (PCA) was performed using the Pearson correlation's coefficient matrix. Several authors state that PCA used as a descriptive method (as in this work), does not require distributional assumptions (including normality) (Quinn and Keough, 2002; Zuur et al., 2007). Factor scores were extracted using a regression method. Furthermore, different Box-Cox transformations were performed for the data but the best correlations were found for the original data.

Atmospheric pressure fields over the Alboran basin were generated using version 3.7.4 of the Fifth-Generation National Center for Atmospheric Research (NCAR) - Penn State Mesoscale Model (MM5, Grell et al., 1994) implemented for Andalusia (south of Spain) and centered at the Strait of Gibraltar. The model simulation was initialized using 1-degree NCEP-GFS analysis (Rutledge et al., 2006) and was first run in non-hydrostatic mode at a $30-\mathrm{km}$ horizontal resolution using one-way nesting. The output from the coarse domain was then used to initialize the $10-\mathrm{km}$ simulation. Both domains had 35 vertical levels. The time step used in integration was $90 \mathrm{~s}$ for the coarse domain and $30 \mathrm{~s}$ for the $10-\mathrm{km}$ domain. The hourly sea-level pressure was derived from surface pressure and adjusted to sea level. Five representative node

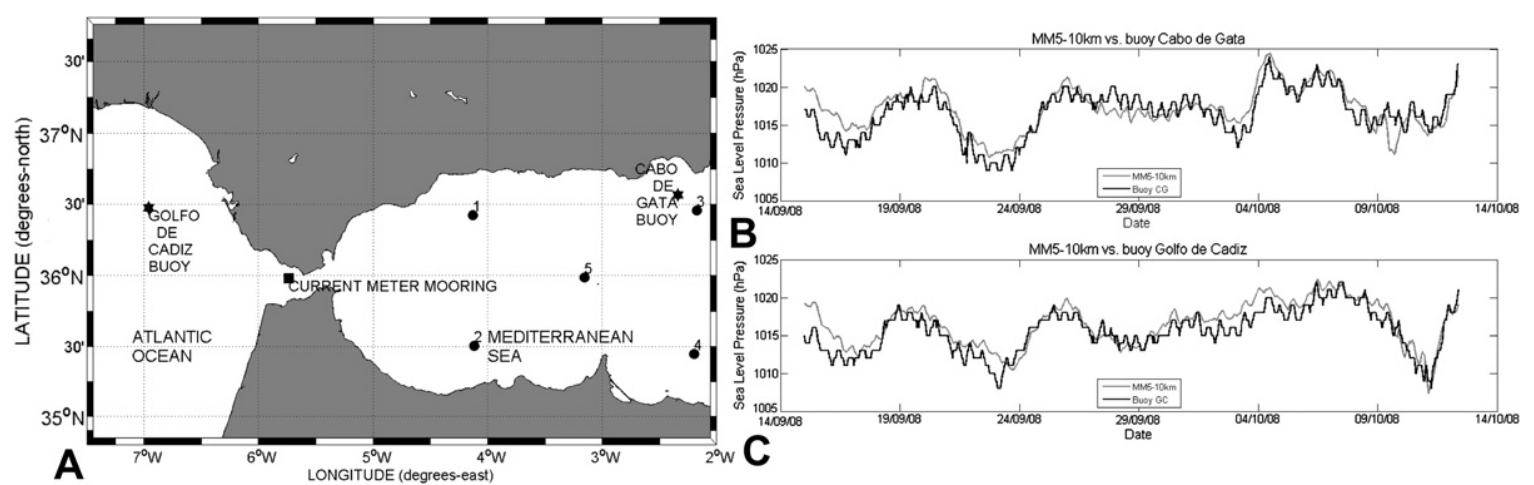

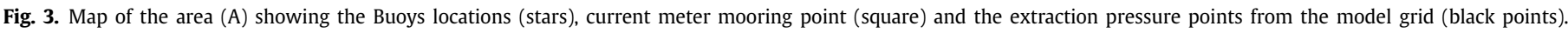
Comparison of sea-level pressure (hPa) between MM5-10 km results (gray line) and buoys data (black line) in Cabo de Gata (B) and Golfo de Cádiz (C) Buoys locations. 
outputs of the Alboran Sea were selected and averaged to obtain the sea-level pressure during the different legs of the cruise. As can be seen in the Fig. $3(\mathrm{~B}, \mathrm{C})$ the model is able to reproduce main patterns of sea-level pressure both sides of the strait (Gulf of Cadiz and Alboran Sea).

Tidal height and tidal currents were predicted to classify the sampling stations (Section 2.2), the prediction of the tidal currents shown in Fig. 2C were based on the tidal constants extracted from the least squares harmonic analysis (Foreman and Henri, 1989) of two years long time series recorded by an ADCP moored at Camarinal Sill ("P" in Fig. 1). Full details could be revised in Alonso Del Rosario et al. (2003). Tidal height prediction has been built on the base of the tidal constants for Tarifa Harbor published in the Admiralty tables of the Spanish Hydrographic Service. Additionally, current velocity (west-east component) was recorded by a onepoint current meter (Anderaa RCM7) located over the Camarinal Sill at a depth of $100 \mathrm{~m}$ ("C" in Fig. 1). The original current velocity series was filtered to isolate the sub-inertial signal (periods greater than $33 \mathrm{~h}$ ) by applying an FFT filter.

In addition, MODIS Level 2 surface chlorophyll images at a 1-km resolution (http://oceancolor.gsfc.nasa.gov/) were used to obtain synoptic images of the region for each different tidal amplitude (spring and neap tides). MODIS chlorophyll images were geolocated, atmospherically-corrected (level-2) and projected.

\subsection{Temporal framework and presentation of results}

The time scale of sampling for the entire grid was on the order of 5 days, so the tidal-scale effects on the distribution of the different variables could not be resolved in the entire domain, which occurs on a scale of hours. Therefore, sampling stations were classified within tidal-specific periods following the same criteria as in Macías et al. (2008b) and assuming homogeneity in the tidal cycles occurring during each tidal amplitude. The tidal cycle was referenced to the tidal level in Tarifa, a town near the middle section of the strait (Fig. 1), and was divided into three stages of $4 \mathrm{~h}$ : HW-2 (from $4 \mathrm{~h}$ before high water to high water, representing conditions before the tidal shift), HW +2 (from high water to $4 \mathrm{~h}$ after high water, representative of the conditions just after the tidal shift) and LW (from $2 \mathrm{~h}$ before low water to $2 \mathrm{~h}$ after low water, coinciding with the deceleration of the inflowing flux).

The selection of these stages was related to the primary hydrodynamic processes known to dominate the strait's dynamics and served as periods of reference to analyze the water mass distribution and plankton patterns along the entire tidal cycle (Macías et al., 2008b). At HW-2 (i.e., shortly before HW), the Camarinal Sill is predicted to have high current velocities and an enhanced outflow that are related to the generation of arrested internal waves (Bruno et al., 2002) and the reversion of the surface Atlantic flow (Izquierdo et al., 2001). These arrested or stationary internal waves are then established over the sill 2-3 h before high water (Alonso Del Rosario et al., 2003), and at HW (when the tide turns), they start to propagate eastward. Around $\mathrm{HW}+2$, both internal waves and the surface Atlantic water move toward the Mediterranean, completely reestablishing the inflow. Around the time of LW, the outflow over the Camarinal Sill begins to increase, and the internal waves created in the previous outflowing phase usually reach the eastern side of the strait (Farmer and Armi, 1988; Macías et al., 2006).

Results are presented in horizontal maps of integrated values up to a 75-m depth, with the sorting of stations being dependent on the tidal stage described above and using the Kriging interpolation.

\section{Results}

\subsection{Water masses and physical structure of the water column}

\subsubsection{Spring tides}

During the entire tidal cycle, surface salinity was constant at both boundaries of the study area. Salinity reached values of 36.2-36.3 in the Atlantic sector and 36.7-36.85 in the Mediterranean side (Fig. 4B, E, H). During HW-2 and just above the Camarinal

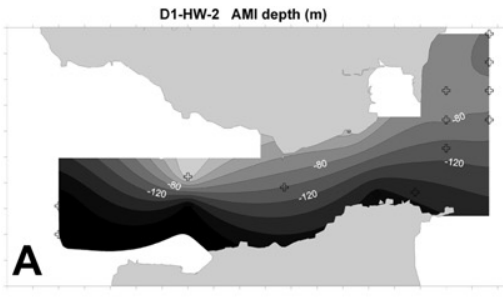

D1-HW+2 AMI Depth (m)

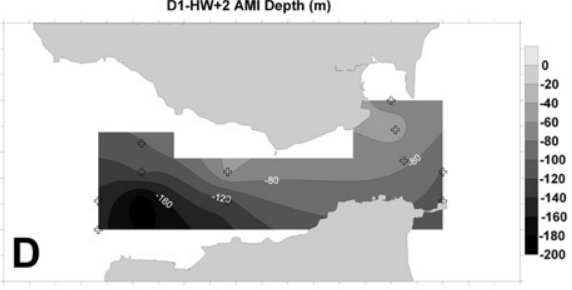

D1-LW AMI Depth (m)

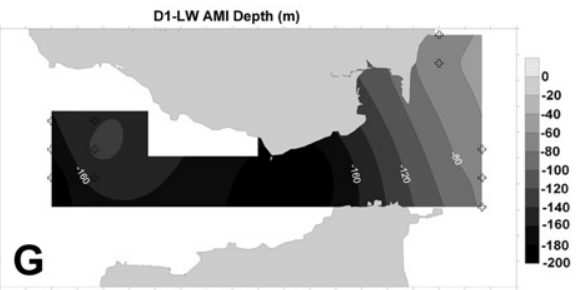

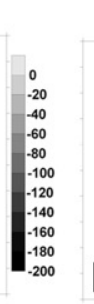

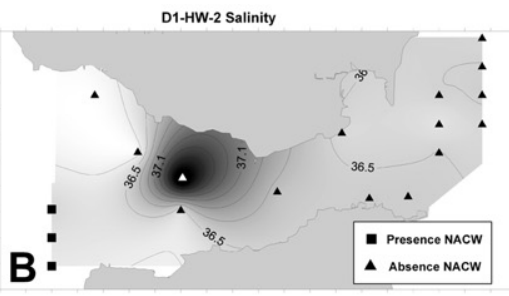

D1-HW+2 Salinity
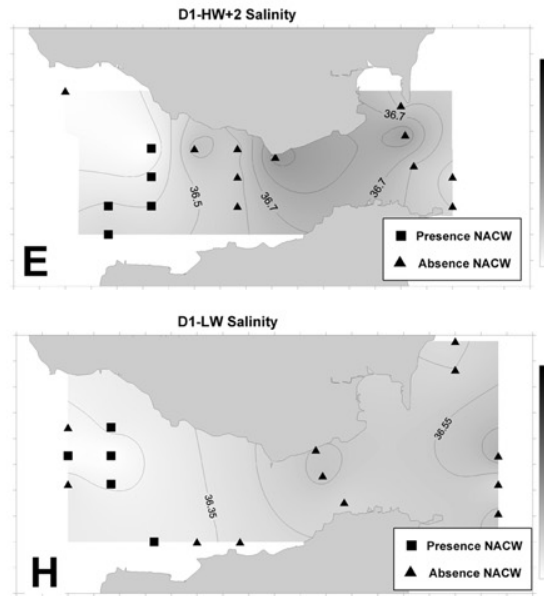
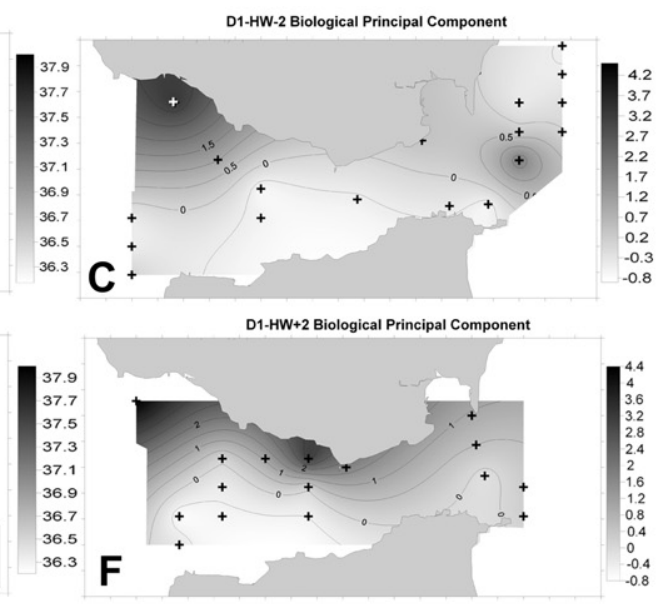

D1-HW+2 Biological Principal Component
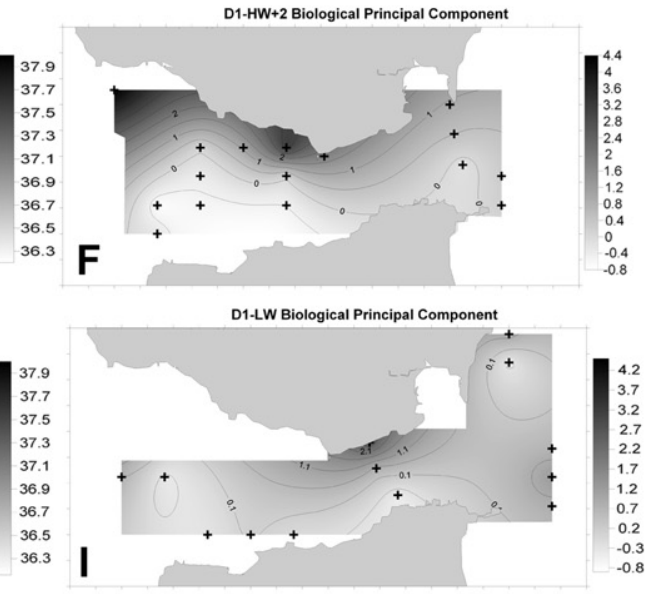

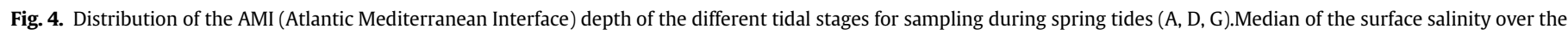
top $75 \mathrm{~m}(\mathrm{~B}, \mathrm{E}, \mathrm{H})$. The presence/absence of NACW is marked by a square/triangle (B, E, H). Factor scores of the principal component for each station (C, F, I). 
Sill, there was a salty patch (salinity $=38$ ) (Fig. 4B). Furthermore, during $\mathrm{HW}+2$, a band of salty water (salinity $=37$ ) was present in the surface layers from the east side of the Camarinal Sill to the eastern sector of the strait (Fig. 4E).

NACW was irregularly distributed, extending primarily in the western region of the study area (Fig. 4B, E, H). This water mass was only detected westward of Cape Espartel (stations marked with squares), but not in the northern coastal platform near Trafalgar Cape.

In general, the AMI was deeper in the southern margin of the strait, an effect that was variable over the tidal cycle, and was more marked at HW-2 (Fig. 4A). The minimum depth $(-10 \mathrm{~m})$ was located over the sill (HW-2) (Fig. 4A). During LW, the pattern of the AMI depth was different from the other tidal stages (Fig. 4G). It was located deeper, with an east-west gradient being the deepest values close to Tarifa. Moving eastward from Tarifa, the gradient became steeper, with the minimum depth located in the northern Alboran coast $(-70 \mathrm{~m})$.

\subsubsection{Neap tides}

Salinity (Fig. 5B, E, H) was low in the western side around Cape Espartel and progressively increased toward the Mediterranean basin. Maximum values (37.2) were observed in the northern Alboran area.

NACW was present at all of the southern stations during HW-2 (Fig. 5B). The presence of NACW was more intermittent during $\mathrm{HW}+2$. It was detected westward of the Camarinal sill around the Tarifa Narrow and at some stations in the southern section of the Alboran Sea (Fig. 5E). During LW, this water mass was only detected at the Atlantic stations, except at the most shallow stations and those located the furthest north (Fig. 5H).

In general, the AMI was deeper $(-200 \mathrm{~m})$ on the Atlantic side (Fig. 5B, D, F) and more shallow on the Mediterranean Side ( $-60 \mathrm{~m}$ ), creating a strong gradient between these areas. This gradient followed a west-east direction on the Atlantic side, but turned to a north-south direction east of the Tarifa Narrows.

\subsection{Biological variables}

Total chlorophyll, active chlorophyll (\%) and chlorophyll contained in large cells (\%; diameter $>20 \mu \mathrm{m}$ ) were highly correlated (Table 1), so these variables were synthesized in a principal component. Only one extracted component had an eigen-value $>1$ (2.310). Bartlett's Test of Sphericity was passed (Chi-square value $=150.181$, degrees of freedom $=3, p<0.01$ ). Furthermore, the component explained $77 \%$ of the system's biological variability and was well correlated with each variable (Table 1). Positive factor scores denote high concentrations of total chlorophyll and high percentages of active and large-cell chlorophyll. Thus, this component could be associated with the gradient from coastal (i.e., more eutrophic) to open ocean (i.e., more oligotrophic) waters.

\subsubsection{Spring tides}

Biological variables had the same general distribution in all tidal stages during spring tides. Maximum values of the principal component were reduced to the north-west platform in a band parallel to the coastline from Trafalgar Cape to the Camarinal Sill (Fig. 4C, F, I). During HW-2, another relative maximum was located in the Alboran Sea between Gibraltar and Ceuta (Fig. 4C). Maximum values of total chlorophyll, chlorophyll in large cells and active chlorophyll varied from $1 \mathrm{mg} \mathrm{m}^{-3}, 50 \%$ and $20 \%$, respectively, in the northern-west coast (factor score $=4.2$ ) to $0.1 \mathrm{mg} \mathrm{m}^{-3}, 5 \%$ and $2 \%$ near Cape Espartel (factor score $=-0.5$ ).

\subsubsection{Neap tides}

During these stages (HW-2 and LW), there was a common pattern in total chlorophyll, chlorophyll in large cells (\%) and active chlorophyll (\%) following the principal component (Fig. 5C, I). Maximum values were found in the northern coastal stations $\left(0.3 \mathrm{mg} \mathrm{m}^{-3}, 10 \%\right.$ and $5 \%$, respectively, factor score $\left.=0.4\right)$ with a "tongue" extending from the coast between Trafalgar Cape and Tarifa to the Camarinal Sill area. However, this feature was more prominent during HW-2 (Fig. 5C) than in LW (Fig. 5I). The

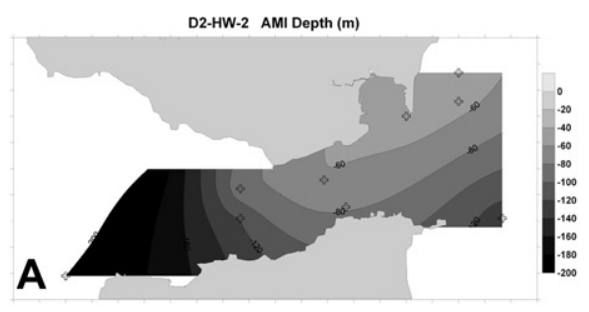

D2-HW+2 AMI Depth (m)

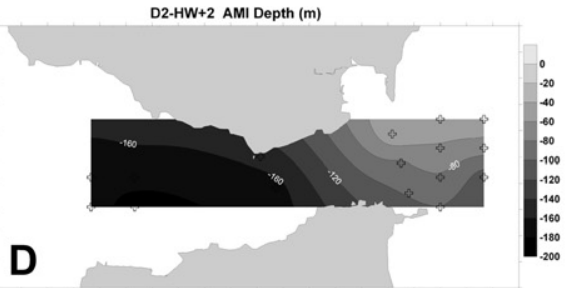

D2-LW AMI Depth (m)

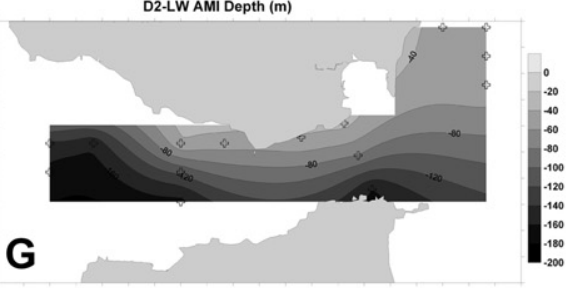

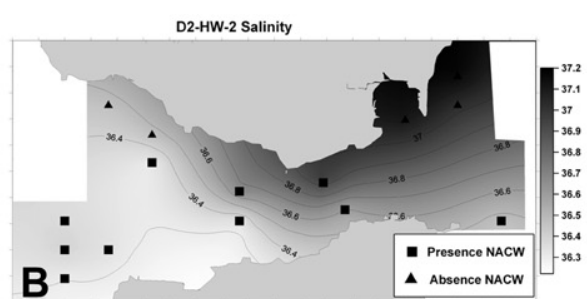

D2-HW+2 Salinity

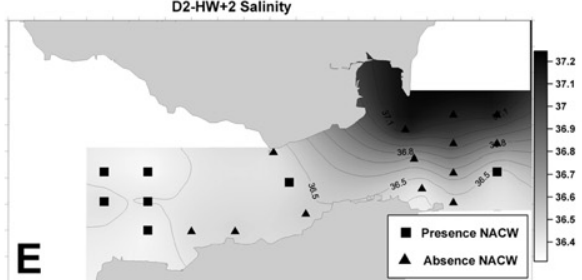

D2-LW Salinity

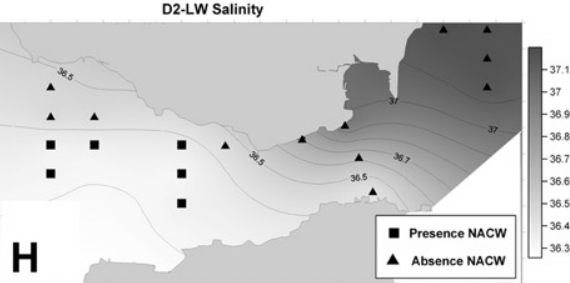

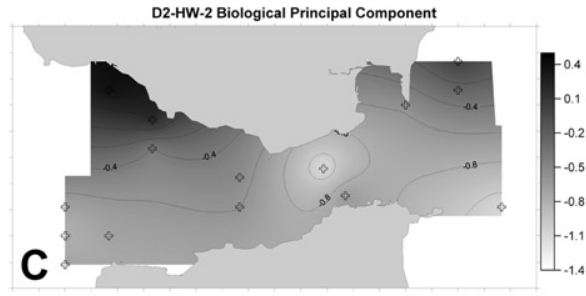

D2-HW+2 Biological Principal Component

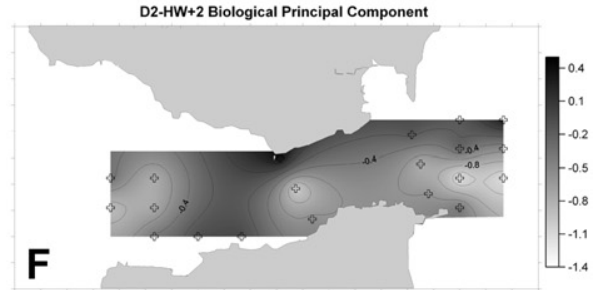

D2-LW Biological Principal Componen

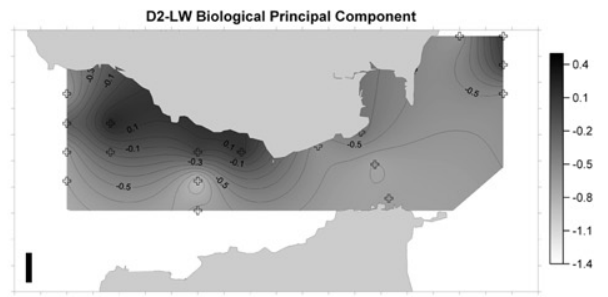

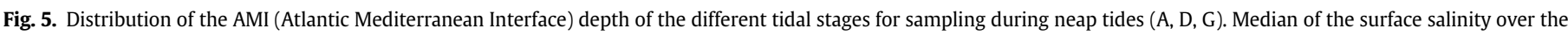
top $75 \mathrm{~m}$ (B, E, H). The presence/absence of NACW is marked by a square/triangle (B, E, H). Factor scores of the principal component for each station (C, F, I). 
Table 1

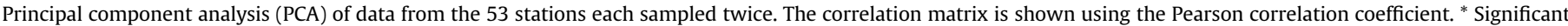

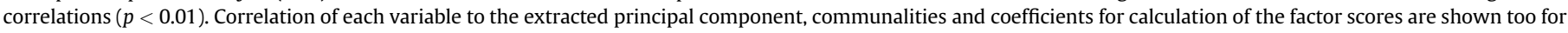
each variable.

\begin{tabular}{|c|c|c|c|c|c|c|}
\hline Variables & Total Chl a & $\% \mathrm{Chl} \mathrm{a}>20 \mu \mathrm{m}$ & \% Active Chl a & Communalities & Principal component & Coefficients \\
\hline Total Chl a & 1 & - & - & 0.840 & 0.917 & 0.397 \\
\hline$\% \mathrm{Chl} \mathrm{a}>20 \mu \mathrm{m}$ & $0.592^{*}$ & 1 & - & 0.649 & 0.805 & 0.349 \\
\hline$\%$ Active Chl a & $0.799 *$ & $0.565^{*}$ & 1 & 0.821 & 0.906 & 0.392 \\
\hline
\end{tabular}

distribution of stations in $\mathrm{HW}+2$ was different than the other tidal stages (Fig. 5F) because the Cape Trafalgar area was not covered. Nevertheless, in this case, the biological variables seemed to have the same "tongue-shaped" distribution, with highest values at both coastal stations on the Atlantic side (north and south coasts).

Mean values of biological variables in this tidal cycle were lower than during spring tides (Table 2A). Total chlorophyll and active and large-cell chlorophyll (\%) were significantly different between spring and neap tides. Furthermore, the loading scores of the PCA were higher during spring tide compared to lower tides.

\section{Discussion}

\subsection{Physical variables}

A simple two-layer approximation could not be enough accurate for the description of the Strait dynamics as it is usually assumed that the interfacial layer plays a crucial role in the water interchange (e.g., Bray et al., 1995; Macías et al., 2007; Sannino et al., 2007). Sannino et al. (2007) showed the midpoint of the interfacial layer placed at $80-100 \mathrm{~m}$ eastward Camarinal Sill with a thickness larger than $120 \mathrm{~m}$. Therefore, our integration of the upper $75 \mathrm{~m}$ should be considered as representative of both the Atlantic and intermediate layers. As commented on above, this section of the water column is the one finally entering in the surface layer of the Alboran Sea and, hence, is the most crucial for the biogeochemical budgets of this basin. So, for the specific purposes of the present study, the two-layer approximation adopted could be considered adequate.

The analyzed data set reinforces the large discontinuity in the physical processes of the strait, highlighting the pulsating nature of this particular environment (Macías et al., 2006). In our results, interfacial mixing associated with internal waves (Wesson and Gregg, 1994; Macías et al., 2007; Sannino et al., 2007) was clearly visible in the high surface salinity values over the Camarinal Sill detected only at HW-2 and during spring tides (Fig. 4B). During spring tides (D1), outflowing currents higher than $1 \mathrm{~m} \mathrm{~s}^{-1}$ were predicted over the Camarinal Sill (Fig. 2C). Consequently, approximately $2-3 \mathrm{~h}$ before high water (HW-2), internal waves should be generated and remain arrested on the Camarinal Sill for approximately 4 h (Vázquez et al., 2008). These mixed waters were

Table 2

Statistics of the sampled variables between the different phases of the survey (spring/neap tides). * Significant differences $(p<0.05)$. Mann-Whitney $U$ test for independent samples was used.

\begin{tabular}{|c|c|c|c|}
\hline \multirow[t]{2}{*}{ Variables } & \multirow{2}{*}{$\frac{\text { D1 }- \text { Spring tides }}{\text { Median }}$} & \multirow{2}{*}{$\frac{\text { D2 - Neap tides }}{\text { Median }}$} & \multirow{2}{*}{$\begin{array}{l}\text { Significant } \\
\text { difference }\end{array}$} \\
\hline & & & \\
\hline \multicolumn{4}{|c|}{ A-Entire domain $(n=53)$} \\
\hline Total Chl a $\left(\mathrm{mg} \mathrm{m}^{-3}\right)$ & 0.21 & 0.16 & $*$ \\
\hline$\%$ Chl a > $20 \mu \mathrm{m}$ & 10.2 & 6 & $*$ \\
\hline$\%$ Active Chl a & 12.4 & 2.85 & $*$ \\
\hline \multicolumn{4}{|c|}{ B-Mediterranean Side $(n=27)$} \\
\hline Total Chl a $\left(\mathrm{mg} \mathrm{m}^{-3}\right)$ & 0.23 & 0.14 & $*$ \\
\hline$\%$ Chl a > $20 \mu \mathrm{m}$ & 10.24 & 6.27 & $*$ \\
\hline$\%$ Active Chl a & 10.34 & 2.85 & $*$ \\
\hline
\end{tabular}

advected westward during the $\mathrm{HW}+2$ period (salty patch along the main channel in Fig. 4E) when the inflow was reestablished, reaching the eastern side of the strait $6 \mathrm{~h}$ after HW (SánchezGarrido et al., 2008; Vázquez et al., 2008). During this phase, westward sub-inertial currents were intensified (Fig. 6B) and favored the generation of large amplitude internal wave events (Vázquez et al., 2008).

It is worth noting that these mixing phenomena may provide a mechanism for nutrient supply to the surface layer of the Alboran Sea. Furthermore, this may provide a way to modify the biogeochemical budget of the Mediterranean Sea through the recirculation of nutrients from deep waters, which would otherwise be lost to the deep Atlantic Ocean (Macías et al., 2007). However, no mixed waters were observed throughout the entire strait during neap tides (see salinity distributions in Fig. 5B, E, H) so this recirculation process is less likely to happen during this tidal conditions.

The inflow of NACW into the Alboran Sea has been described as an additional mechanism for nutrient input to the surface waters of the basin (Gómez et al., 2001). However, the input has typically been described as an intermittent process directly related to the tidal amplitude (Gascard and Richez, 1985; Gómez et al., 2001; Macías et al., 2006); because of the intense tidal flows and strong vertical mixing above the Camarinal Sill (Wesson and Gregg, 1994; Sannino et al., 2007) that makes NACW less identifiable (Macías et al., 2008b).This was observed in the present study, as no NACW signal was detected eastward of the Camarinal Sill during spring tides (Fig. 4B, E, H). On the other hand, during neap tides, NACW is able to overcome the sill more easily (Fig. 5B, E, H), especially on the southern side of the main channel concomitant with the deeper AMI (see below). However, enhanced westward sub-inertial currents (Fig. 6B) could reduce the Atlantic inflow, and this condition could impede a larger input of NACW (Macías et al., 2008a).

On the tidal-scale, the AMI depth was controlled by two main phenomena: (1) large amplitude internal waves raising the interface to $\sim 10 \mathrm{~m}$, close to the Camarinal Sill (during HW-2 in spring tides, Fig. 4A) and (2) the Coriolis force proportional to the Atlantic Jet velocity. When the inflow was reinforced (at $\mathrm{HW}+2$ ), the water within the AJ was forced toward the south side of the strait, and the AMI was located deeper in the southern part of the channel, creating a steep latitudinal gradient (Figs. 4E and 5F). This Coriolis forcing, therefore, brings deep waters that are rich in nutrients close to the surface of the northern section of the strait. This shallower AMI could be broken more easily by additional mixing mechanisms, such as those induced by the eastwardpropagating internal waves reaching the proximity of the Algeciras Bay (Sannino et al., 2007). This process could help to explain the quasi-permanent chlorophyll enrichment of the northeastern side of the channel of the strait (Gómez et al., 2000; Macías et al., 2006).

In our results, clear and different patterns in the AMI depth were observed for neap and spring tidal cycles (Figs. 4A, D, G and 5A, D, $G)$. By grouping the stations independent of the spring/neap cycles, Bray et al. (1990) described an average AMI geography and proposed a semi-diurnal cycle for the AMI depth. However, while their mean interface geography is quite similar to the neap tide's 

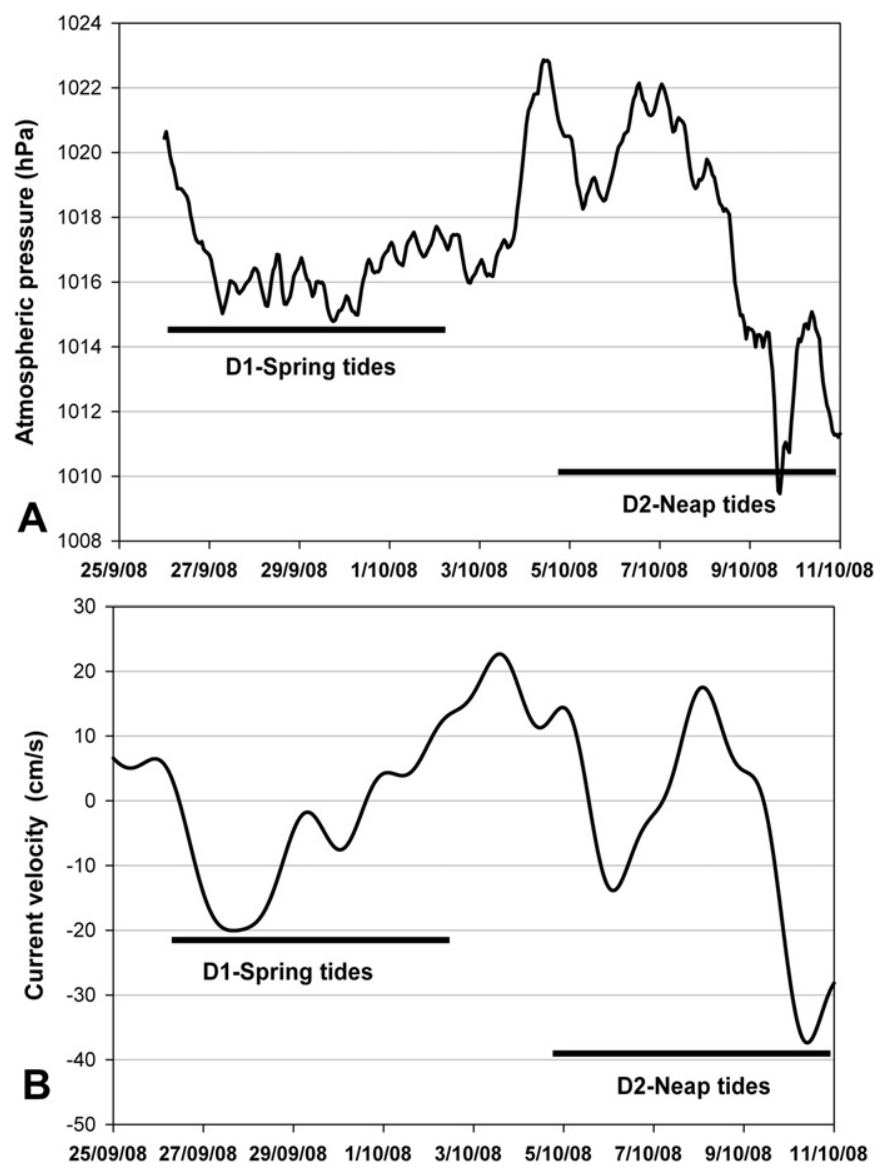

Fig. 6. Time series of simulated mean atmospheric pressure in the Alboran Sea during the cruise (A). Time series of sub-inertial currents over the Camarinal Sill during the cruise (B). Positive and negative values indicate currents toward the Mediterranean and Atlantic, respectively. The lengths of the spring/neap tidal phases are indicated.

distribution presented here (Fig. 5A, D, G), the spring tide distribution (Fig. 4A, D, G) differs considerably. Furthermore, these authors proposed a general semi-diurnal cycle showing high oscillations of the AMI depth over the Camarinal Sill, as in the spring tidal cycle shown here (Fig. 5A, D, G). However, this differs from the neap tide distribution of the AMI presented here (Fig. 5A, $D, G)$. Thus, the different response to tidal forcing should be taken into account to describe the different behavior of the AMI depth separately during neap and spring tides.

\subsection{Biological variables}

Atlantic waters were clearly present in the western region of the Strait of Gibraltar, especially near Cape Espartel. These water masses originate from the anticyclonic, quasi-permanent gyre in the Gulf of Cadiz (Criado-Aldeanueva et al., 2006; García Lafuente and Ruiz, 2007), contained a biological signature typical of surface open-sea waters (Navarro et al., 2006; Macías et al., 2008a), that was characterized by a low chlorophyll concentration and low percentages of active and large-cell chlorophyll (see Results, 3.2, Figs. 4C, F, I and 5C, F, I).

Coastal areas, especially in the northern shelf platform in the neighborhood of Cape Trafalgar, had high levels of chlorophyll and high percentages of active and large-cell chlorophyll (Fig. 4C, F, I). This zone has specific dynamics within the Gulf of Cadiz with an intense bloom in September (Navarro and Ruiz, 2006) due to a highly localized input of nutrients in the surface layer from mixing and tide-topography interactions (Vargas-Yánez et al., 2002). At the same time, the dominant mesoscale circulation seems to increase the water residence time in this region, protecting this area from the intense hydrodynamics of the main channel (Vázquez et al., 2009) and, hence, increasing biological productivity.

Our sampling grid did not cover the submarine ridge extending offshore from Trafalgar Cape because of problems with the draught of the oceanographic vessel. Satellite images show that, during spring tides, the area occupied by the bloom extended far (Fig. 7A, B) and reached the adjacent sampled area (Fig. 4C, F, I). However, the high chlorophyll zone near Cape Trafalgar had lower values and occupied a smaller area during neap tides (Fig. 7C). Consequently, there was a considerable reduction in chlorophyll and other biological variables in the sampled region (Table 2 and Fig. 5C, F, I). During neap tides, the low tidal currents would not create strong mixing in the region, and the input of nutrients to the surface layer should be lower. This reduction in local upwelling could apparently disagree with the occurrence of a bloom at this time of year, as was previously reported by Navarro and Ruiz (2006). However, in this previous work, weekly-integrated satellite images were used, so the effects of the change in the tidal amplitude could not be observed.

On the Atlantic side of the strait, clear differences in biological signatures between both coastal zones were visible (see Results, 3.2), with northern areas having higher biological activity than southern areas. However, during neap tide conditions (Fig. 5C, F, I), there was a "tongue" of relatively high chlorophyll values extending from the north coast to the center of the channel. During this neap tidal cycle, the predicted tidal outflow velocity was very weak (almost non-existent) (Fig. 2C); thus, no Type I internal waves were expected (Vázquez et al., 2008). However, outflowing sub-inertial currents were reinforced during certain stages (Fig. 6B), and this could enhance the generation of Type II internal waves. This suggests that surface divergences and coastal suction are associated with these smaller topographic internal arrested waves typical of neap tides (Bruno et al., 2002). These tongue-shaped structures were also found in satellite data by Vázquez et al. (2009) during spring tides, but we present here the first evidence of this process during neap tides (Figs. 5C, F, I and 7C).

The generation of internal waves over the Camarinal Sill during spring tides (Bruno et al., 2002; Vázquez et al., 2008) has been observed to coincide with the suction of coastal waters (e.g., Vázquez et al., 2009), which introduce high chlorophyll patches within the main along-strait circulation (Macías et al., 2006, 2008b; Bartual et al., 2011). In our data, a high chlorophyll patch was observed at the eastern entrance of the strait during HW-2 at spring tides (Fig. 4C), which could originate from the suction of coastal waters in the previous outflowing event (see details of the mechanics and timing in Macías et al. (2006)). The trace of the coastal suction as a "tongue" of high chlorophyll extending from the north coast to the channel could not be detected clearly in our sampled stations, likely due to the spatial resolution of the grid (Fig. 4C). However, in Fig. 7B, this structure could be found extending from both coastal areas to the main channel around the Camarinal Sill.

High-level pressures were simulated in the Alboran Sea throughout the survey (Fig. 6A), and the derived sub-inertial currents did not favor the inflowing tidal currents (Fig. 6B). These atmospheric conditions reduced the Atlantic inflow and displaced the AJ southward, flowing in a south-east direction (Macías et al., 2008a). Furthermore, coastal upwelling in the northwestern Alboran Sea was not favored by these conditions (Macías et al., 2008a), and the absence of active upwelling can be noticed in Fig. 7(A, B, C). Thus, on the Mediterranean side of the sampled grid, 

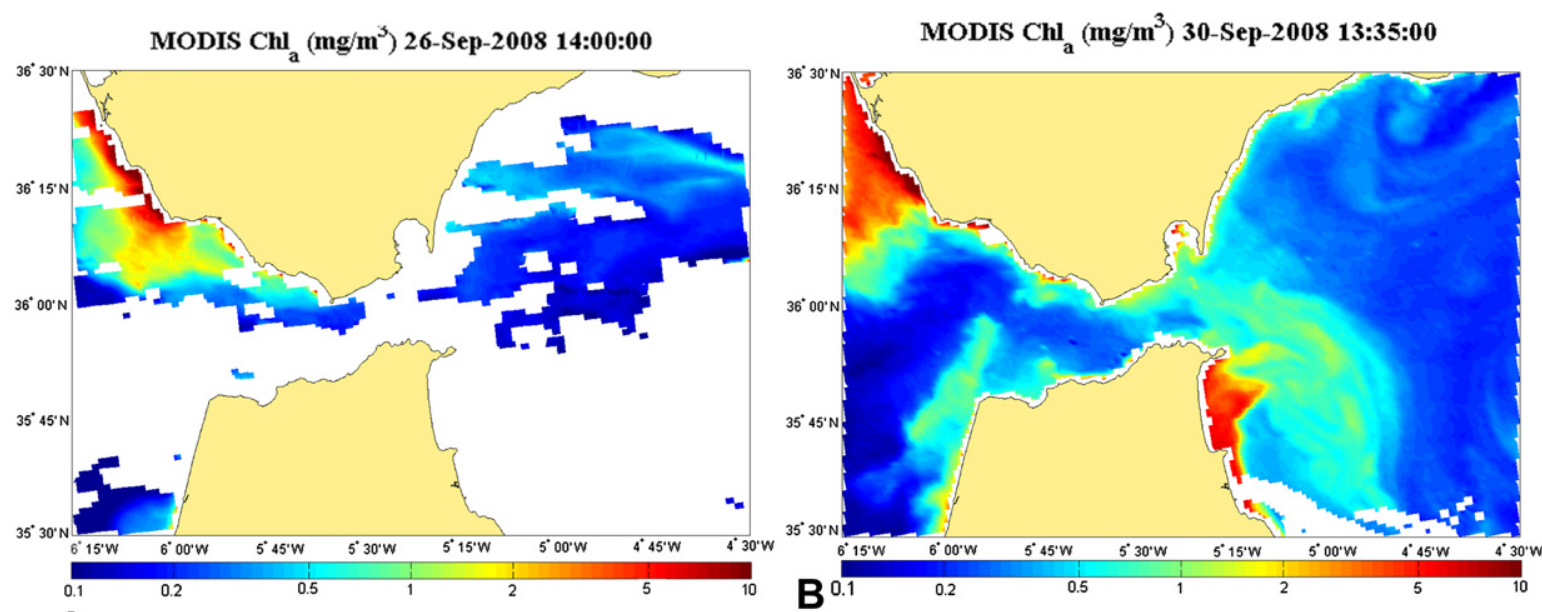

A

MODIS Chl ${ }_{\mathrm{a}}\left(\mathrm{mg} / \mathrm{m}^{3}\right)$ 04-Oct-2008 13:10:00

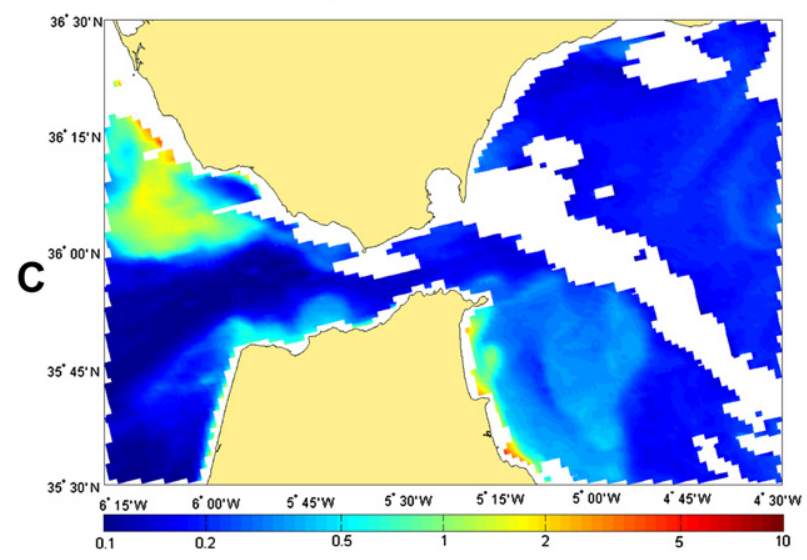

Fig. 7. Representative MODIS chlorophyll images for spring tides (A) (26/09/2008) and (B) (30/09/2008) and neap tides (C) (04/10/2010).

the origin of the measured chlorophyll should only be associated with the Atlantic inflow. In addition, on the Mediterranean side of the strait, mean chlorophyll concentration (and \% active chlorophyll) was significantly higher during spring tides (Table 2B), indicating a stronger coastal suction under these tidal conditions. Moreover, the environmental conditions of the chlorophyll patches moving toward the Alboran Sea should be different during spring and neap tides. Phytoplankton growth should be intensified during spring tides because of the mixing processes over the Sill, which are concomitant with coastal suction (Macías et al., 2007). This should bring phytoplankton and relatively high nutrient concentrations together at the surface during spring tides, as confirmed by the higher \% of active chlorophyll during D1 (Table 2B).

This work represents the first comprehensive description of the submesoscale biogeochemical features in this area, including the effects of arrested internal waves and their releasing in the Strait of Gibraltar and the adjacent Alboran Sea. On the western side of the strait, the main phenomena were the mixing processes over the sill (only during spring tides). Another important process was the suction of high chlorophyll coastal waters from the northern platform, with high biological activity. This suction occurred during both spring and neap tides, but the arrival of chlorophyll in the Alboran Sea was more evident during spring tides. In the Alboran Sea, these processes caused the pulsating arrival of advected waters rich in large cells and active chlorophyll. Two mechanisms of nutrient inputs to the surface layer are proposed for this area: mixed Atlantic-Mediterranean waters (during spring tides) and the inflow of NACW to the $\mathrm{AJ}$ (during neap tides).

\section{Acknowledgments}

This work was supported by the Spanish National Research Plan; projects: CTM2005-08142C03-01 and CTM2008-06124. E.R-R was supported by a grant from the FPU fellowship program. D.M. was supported by a JaeDOC contract (\#XOSC000087) of the Spanish Council for Scientific Research (CSIC).

\section{References}

Alonso Del Rosario, J.J., Bruno, M., Vázquez, A., 2003. The influence of tidal hydrodynamic conditions on the generation of lee waves at the main sill of the Strait of Gibraltar. Deep-Sea Research Part I-Oceanographic Research Papers 50, 1005-1021.

Armi, L., Farmer, D., 1985. The internal hydraulics of the Strait of Gibraltar and associated sills and narrows. Oceanologica Acta 8 (1), 37-46.

Bartual, A., Macías, D., Gutiérrez-Rodríguez, A., García, C.M., Echevarría, F., 2011 Transient pulses of primary production generated by undulatory processes in the western sector of the Strait of Gibraltar. Journal of Marine Systems 87 (1), $25-36$.

Bray, N.A., Winan, C.D., Kinder, T.H., Candela, J., 1990. Generation and kinematics of the internal tide in the Strait of Gibraltar. In: Pratt, L.J. (Ed.), The Physical Oceanography of Sea Straits. Kluwer, Boston, pp. 477-491.

Bray, N.A., Ochoa, J., Kinder, T.H., 1995. The role of interface in exchange through the Strait of Gibraltar. Journal of Geophysical Research 100 (C6), $10755-10776$

Bruno, M., Mañanes, R., Alonso, J.J., Izquierdo, A., Álvarez, O., 1999. An experimental method to investigate the role of low frequency phenomena in the generation of tidal residues. Scientia Marina 63 (2), 165-175.

Bruno, M., Alonso, J.J., Cózar, A., Vidal, J., Ruiz-Cañavate, A., Echevarría, F., Ruiz, J., 2002. The boiling-water phenomena at Camarinal Sill, the Strait of Gibraltar. Deep-Sea Research Part II-Topical Studies in Oceanography 49 (19), 4097-4113. 
Bryden, H.L., Candela, J., Kinder, T.H., 1994. Exchange through the Strait of Gibraltar. Progress in Oceanography 33 (3), 201-248.

Candela, J., Winant, C.D., Bryden, H.L., 1989. Meteorologically forced subinertial flows through the Strait of Gibraltar. Journal of Geophysical Research-Oceans 94 (C9), 12667-12679.

Crepon, M., 1965. Influence de la presion atmospherique sur le niveau moyen de la Mediterranee Occidentale el sur le flux a travers le Detroit de Gibraltar. Cahiers Oceanographiques $1,15-23$.

Criado-Aldeanueva, F., Garcia-Lafuente, J., Vargas, J.M., Del Rio, J., Vazquez, A. Reul, A., Sanchez, A., 2006. Distribution and circulation of water masses in the Gulf of Cadiz from in situ observations. Deep-Sea Research Part II-Topical Studies in Oceanography 53 (11-13), 1144-1160.

Echevarría, F., García Lafuente, J., Bruno, M., Gorsky, G., Goutx, M., Gonzalez, N., Garcia, C.M., Gomez, F., Vargas, J.M., Picheral, M., Striby, L., Varela, M., Alonso, J.J., Reul, A., Cozar, A., Prieto, L., Sarhan, T., Plaza, F., Jimenez-Gomez, F., 2002. Physical-biological coupling in the Strait of Gibraltar. Deep-Sea Research Part II-Topical Studies in Oceanography 49 (19), 4115-4130.

Farmer, D.M., Armi, L., 1988. The flow of Atlantic water through the Strait of Gibraltar - the flow of Mediterranean water through the Strait of Gibraltar Progress in Oceanography 21, 1-105.

Foreman, M.G.G., Henri, R.F., 1989. The harmonic analysis of tidal model time series. Advances in Water Resources 12, 109-120

García Lafuente, J., Vargas, J.M., Candela, J., Bascheck, B., Plaza, F., Sarhan, T., 2000. The tide at the eastern section of the Strait of Gibraltar. Journal of Geophysical Research 105 (C6), 14197-14213.

García Lafuente, J., Delgado, J., Vargas, J.M., Vargas, M., Plaza, F., Sarhan, T., 2002. Low frequency variability of the exchanged flows through the Strait of Gibraltar during CANIGO. Deep-Sea Research Part II-Topical Studies in Oceanography 49 (19), 4051-4067.

García Lafuente, J., Ruiz, J., 2007. The Gulf of Cádiz pelagic ecosystem: a review. Progress in Oceanography 74 (2-3), 228-251.

Gascard, J.C., Richez, C., 1985. Water masses and circulation in the western Alboran Sea and in the Straits of Gibraltar. Progress in Oceanography 15 (3), $157-216$.

Grell, G.A., Dudhia, J., Stauffer, D.R., 1994. A description of the fifth-generation Penn State/NCAR mesoscale model (MM5). NCAR Technical Note NCAR/TN-3981STR, p. 117.

Gómez, F., Echevarría, F., García, C.M., Prieto, L., Ruiz, J., Reul, A., Jiménez-Gómez, F. Varela, M., 2000. Microplankton distribution in the Strait of Gibraltar: coupling between organisms and hydrodynamic structures. Journal of Plankton Research 22 (4), 603-617.

Gómez, F., Gorsky, G., Striby, L., Vargas, J.M., González, N., Picheral, M., GarcíaLafuente, J., Varela, M., Goutx, M., 2001. Small-scale temporal variations in biogeochemical features in the Strait of Gibraltar, Mediterranean side - the role of NACW and the interface oscillation. Journal of Marine Systems 30 (3-4), 207-220.

Holm-Hassen, O., Lorenzen, C.J., Homes, R.W., Strickland, J.D.H., 1965. Fluorometric determination of chlorophyll. Journal Conseil Permanent International l'Exploration de la Mer 187, 9-18.

Izquierdo, A., Tejedor, L., Sein, D.V., Backhaus, J.O., Brandt, P., Rubino, A., Kagan, B.A., 2001. Control variability and internal bore evolution in the strait of Gibraltar: a 2-D two-layer model study. Estuarine, Coastal and Shelf Science 53 (5), 637-651.

Kolberg, Z., Falkowski, P.G., 1993. Use of active fluorescence to estimate phytoplankton photosynthesis in situ. Limnology and Oceanography 38 (8), 1646-1665.

Kolbowski, J., Schreiber, U., 1995. Computer-controlled phytoplankton analyzer based on a 4-wavelengths PAM chlorophyll fluorometer. In: Mathis, V.P. (Ed.) Photosynthesis, from Light to Biosphere. Kluwer Academic Publishers, Dordrecht, The Netherlands, pp. 825-828.

Lacombe, H., Richez, C., 1982. The regime of the Strait of Gibraltar. In: Nihoul, J.C.J. (Ed.), Hydrodynamics of Semi-Enclosed Seas. Elsevier Sci. Publ. Comp., New York, pp. 13-73.
Macías, D., García, C.M., Echevarría, F., Vázquez, A., Bruno, M., 2006. Tidal induced variability of mixing processes on Camarinal Sill (Strait of Gibraltar): a pulsating event. Journal of Marine Systems 60, 177-192.

Macías, D., Martin, A.P., García-Lafuente, J., García, C.M., Yool, A., Bruno, M. Vázquez, A., Izquierdo, A., Sein, D.V., Echevarría, F., 2007. Analysis of mixing and biogeochemical tides on the Atlantic-Mediterranean effects induced by flow in the Strait of Gibraltar through a physical-biological coupled model. Progress in Oceanography $74(2-3), 252-272$.

Macías, D., Bruno, M., Echevarria, F., Vazquez, A., Garcia, C.M., 2008a. Meteorologically-induced mesoscale variability of the North-western Alboran Sea (southern Spain) and related biological patterns. Estuarine, Coastal and Shelf Science 78 (2), 250-266.

Macías, D., Lubián, L.M., Echevarría, F., Huertas, I.E., García, C.M., 2008b. Chlorophyll maxima and water mass interfaces: tidally induced dynamics in the Strait of Gibraltar. Deep-Sea Research Part I-Oceanographic Research Papers 55 (7) 832-846.

Macías, D., Navarro, G., Bartual, A., Echevarría, F., Huertas, I.E., 2009. Primary production in the Strait of Gibraltar: carbon fixation rates in relation to hydrodynamic and phytoplankton dynamics. Estuarine, Coastal and Shelf Science 83 (2), 197-210.

Navarro, G., Ruiz, J., Huertas, I.E., Garcia, C.M., Criado-Aldeanueva, F., Echevarria, F. 2006. Basin-scale structures governing the position of the deep fluorescence maximum in the Gulf of Cadiz. Deep-Sea Research Part II-Topical Studies in Oceanography 53 (11-13), 1261-1281.

Navarro, G., Ruiz, J., 2006. Spatial and temporal variability of phytoplankton in the Gulf of Cadiz through remote sensing images. Deep-Sea Research Part II-Topical Studies in Oceanography 53 (11-13), 1241-1260.

Quinn, G., Keough, M., 2002. Experimental Design and Data Analysis for Biologists. Cambridge University Press, United States of America, p. 537.

Rutledge, G.K., Alpert, J., Ebisuzaki, W., 2006. NOMADS: a climate and weather model archive at the National Oceanic and Atmospheric Administration. Bulletin of the American Meteorological Society 87, 327-341.

Sánchez-Garrido, J.C., García Lafuente, J., Criado Aldeanueva, F., Baquerizo, A. Sannino, G., 2008. Time-spatial variability observed in velocity of propagation of the internal bore in the Strait of Gibraltar. Journal of Geophysical Research 113 (C07034). doi:10.1029/2007JC004624.

Sánchez-Román, A., Criado-Aldeanueva, F., García-Lafuente, J., Sánchez, J.C., 2008 Vertical structure of tidal currents over Espartel and Camarinal sills, Strait of Gibraltar. Journal of Marine Systems 74 (1-2), 120-133.

Sannino, G., Carillo, A., Artale, V., 2007. Three-layer view of transports and hydraulics in the Strait of Gibraltar: a three-dimensional model study. Journal of Geophysical Research 112 (C03010). doi:10.1029/2006JC003717.

Tsimplis, M.N., Bryden, H.L., 2000. Estimation of the transports through the Strait of Gibraltar. Deep-Sea Research Part I-Oceanographic Research Papers 47 (12), 2219-2242.

Vargas-Yánez, M., Viola, T.S., Jorge, F.P., Rubin, J.P., García-Martinez, M.C., 2002. The influence of tide-topography interaction on low-frequency heat and nutrient fluxes. Application to Cape Trafalgar. Continental Shelf Research 22 (1) 115-139.

Vázquez, A., Bruno, M., Izquierdo, A., Macías, D., Ruiz-Cañavate, A., 2008. Meteorologically forced subinertial flows and internal wave generation at the main sill of the Strait of Gibraltar. Deep-Sea Research Part I-Oceanographic Research Papers 55 (10), 1277-1283.

Vázquez, A., Flecha, S., Bruno, M., Macías, D., Navarro, G., 2009. Internal waves and short-scale distribution patterns of chlorophyll in the Strait of Gibraltar and Alboran Sea. Geophysical Research Letters 36.

Wesson, J.C., Gregg, M.C., 1994. Mixing at Camarinal Sill in the Strait of Gibraltar Journal of Geophysical Research 99, 9847-9878.

Yentsch, C.S., Menzel, D.W., 1963. A method for the determination of phytoplankton chlorophyll and Phaeophytin by fluorescence. Deep-Sea Research 10 (3), 221-231.

Zuur, A.F., Ieno, E.N., Smith, G.M., 2007. Analysing Ecological Data (Statistics for Biology and Health). Springer, United States of America, p. 672. 